\title{
Pengaruh Keterampilan Kewirausahaan, Orientasi pasar dan Orientasi Penjualan terhadap Kinerja Usaha UMKM
}

\author{
Jessica Rizan dan Louis Utama \\ Program Studi Manajemen Fakultas Ekonomi \& Bisnis \\ Universitas Tarumanagara, Jakarta \\ Email: Jessica.115150409@stu.untar.ac.id
}

\begin{abstract}
The purpose of this study is to find out 1) To find out whether entrepreneurship skills have an influence on the performance of micro and small businesses in the culinary field in North Jakarta.2) To find out whether market orientation has an influence on the performance of micro and small businesses in the culinary sector in North Jakarta. 3) To find out whether sales orientation has an influence on the performance of micro and small businesses in the culinary sector in North Jakarta. The population in this study were entrepreneur in Jakarta. The sample used in this study was 40 respondents from micro small medium enterprises in North Jakarta. The sampling technique used was nonprobability sample with purposive sampling sampling method. Overall the results of this study are 1) Entrepreneurial skills have an influence on the performance of micro and small businesses in the culinary field in North Jakarta, 2) Market orientation has an influence on the performance of micro and small businesses in the culinary sector in North Jakarta, 3) Sales orientation has an influence on the performance of micro small and medium enterprises in the culinary sector in North Jakarta.
\end{abstract}

Keywords: Entrepreneur, Market Orientation, Sales Orientation, Performance

Abstrak: Tujuan penelitian ini adalah untuk mengetahui 1) Untuk mengetahui apakah keterampilan kewirausahaan memiliki pengaruh terhadap kinerja usaha mikro kecil dan menengah pada bidang kuliner di Jakarta Utara. 2) Untuk mengetahui apakah orientasi pasar memiliki pengaruh terhadap kinerja usaha mikro kecil dan menengah pada bidang kuliner di Jakarta Utara. 3) Untuk mengetahui apakah orientasi penjualan memiliki pengaruh terhadap kinerja usaha mikro kecil dan menengah pada bidang kuliner di Jakarta Utara. Populasi dalam penelitian ini adalah wirausaha di Jakarta. Sampel yang digunakan pada penelitian ini yaitu 40 responden wirausaha di Jakarta Utara. Teknik pengambilan sampel yang digunakan yaitu nonprobability sample dengan metode pengambilan sampel purposive sampling. Secara keseluruhan hasil dari penelitian ini yaitu 1) Keterampilan kewirausahaan memiliki pengaruh terhadap kinerja usaha mikro kecil dan menengah pada bidang kuliner di Jakarta Utara, 2) Orientasi pasar memiliki pengaruh terhadap kinerja usaha mikro kecil dan menengah pada bidang kuliner di Jakarta Utara , 3) Orientasi penjualan memiliki pengaruh terhadap kinerja usaha mikro kecil dan menengah pada bidang kuliner di Jakarta Utara.

Kata kunci: Kewirausahaan, Orientasi Pasar, Orientasi Penjualan, Kinerja

\section{LATAR BELAKANG}

Kegiatan kewirausahaan di sektor formal dan informal sangat signifikan untuk pertumbuhan ekonomi dan pembangunan nasional (Al-Mamun et al., 2016). Secara khusus, usaha mikro dan kecil, sebagai pendorong kewirausahaan pribumi, memainkan peran penting dalam mengembangkan ekonomi global dengan meningkatkan pembangunan kemampuan teknologi, difusi inovasi dan mobilisasi modal (Nabiswa \& Mukwa, 2017). Pada saat yang 
sama, perusahaan di tingkat global menghadapi banyak tantangan dalam bentuk ketidakpastian pasar, modal manusia dan keuangan dan peningkatan pesaing lokal dan internasional (Raghuvanshi \& Garg, 2018). Inilah sebabnya mengapa OECD dan negaranegara yang berpartisipasi menekankan pada kewirausahaan, tidak hanya dengan meningkatkan jumlah pengusaha tetapi juga dengan menciptakan lebih banyak perusahaan dan pertumbuhan lapangan kerja untuk jaring pengaman sosial.

Seorang wirausaha perlu selalu berinovasi dan berpikiran inovatif dalam memanfaatkan peluang, salah satu peluang yang bisa diambil oleh wirausaha adalah pengadopsian keterampilan kewirausahaan. Keterampilan kewirausahaan merujuk pada kegiatan atau pengetahuan yang dapat membangun dan mengoperasikan perusahaan dengan sukses (Liñán \& Chen, 2009). Dalam penelitian kewirausahaan bisnis kecil, keterampilan kewirausahaan telah dikaitkan dengan karakteristik demografis, psikologis dan perilaku dan keterampilan teknis yang memiliki dampak yang lebih kuat pada kinerja perusahaan (Gerli et al., 2011)

Kurangnya keterampilan kewirausahaan akan menyebabkan seorang wirausaha sulit untuk memfasilitasi usahanya karena kurang kapabilitas dan pengetahuan yang akan berdampak pada kinerja usahanya (Tehseen \& Ramayah, 2015). Padahal pada studi sebelumnya menunjukkan bahwa keterampilan kewirausahaan berperan penting pada kinerja perusahaan, dalam pertumbuhan dan profitabilitas (Mitchelmore \& Rowley, 2010)

Setelah seorang wirausaha mengadopsi keterampilan kewirausahaan, seorang wirausaha juga perlu memperhatikan tentang orientasi pasar atau orientasi pasar. Orientasi pasar didefinisikan sebagai orientasi perusahaan terhadap promosi dan dukungan untuk pengumpulan, penyebaran, dan responsif terhadap intelijen pasar untuk memenuhi kebutuhan pelanggan yang dapat menjamin kinerja perusahaan (Kohli \& Jaworski, 1990). Orientasi pasar juga dipengaruhi oleh perubahan kebutuhan dan preferensi pasar, tingkat kewirausahaan dan orientasi pasar yang tinggi meningkatkan kinerja perusahaan (Boso et al., 2013)

Apabila seorang wirausaha tidak memperhatikan orientasi pasar, pendekatan yang ia lakukan pada orientasi pasar akan menjadi tidak efektif dan tidak dapat memfasilitasi organisasi untuk berkinerja luar biasa karena wirausaha tersebut kurang memahami kebutuhan dan keinginan konsumen mereka, strategi dan kemampuan pesaing, persyaratan dan pengembangan saluran distribusi dan lingkungan pasar yang lebih luas (Morgan et al., 2009).

Setelah seorang wirausaha mengadopsi orientasi pasar, ia juga perlu memperhatikan tentang orientasi penjualan. Orientasi penjualan mengacu pada wirausaha yang terlibat dalam kegiatan penjualan yang membutuhkan "mendapatkan suatu penjualan" dari setiap pelanggan (Jaramillo et al., 2007). Pendekatan ini berfokus pada penjualan sebanyak mungkin dimana kebutuhan pelanggan diprioritaskan dalam lingkungan kerja yang mendukung (Boles et al., 2001). Wirausaha yang kurang mengadopsi orientasi penjualan akan kurang berorientasi pada kepuasan konsumen, kurang mempresentasikan layanan / produk mereka dan kurangnya penjualan, wirausaha juga akan kurang terlibat dalam beberapa perilaku yang berorientasi pada penjualan (Boles et al., 2001).

\section{KAJIAN TEORI}

Keterampilan kewirausahaan merujuk pada kegiatan atau pengetahuan yang dapat membangun dan mengoperasikan perusahaan dengan sukses (Liñán \& Chen, 2009). Keterampilan kewirausahaan merujuk pada kemungkinan belajar dan mengadopsi karakteristik eksklusif yang penting untuk melakukan tugas kewirausahaan yang melibatkan interaksi dalam lingkungan sosial dan material (Pyysiäinen et al., 2006). Orientasi wirausaha 
mencerminkan kecenderungan perusahaan untuk terlibat dalam perilaku inovatif, berani mengambil resiko dan proaktif untuk mengalahkan pesaing (Utama \& Nadi, 2017).

Orientasi pasar didefinisikan sebagai orientasi perusahaan terhadap promosi dan dukungan untuk pengumpulan, penyebaran, dan responsif terhadap intelijen pasar untuk memenuhi kebutuhan pelanggan yang dapat menjamin kinerja perusahaan (Kohli dan Jaworski, 1990).

Orientasi pasar sebagai budaya organisasi yang meningkatkan kompetensi untuk menciptakan nilai superior bagi pembeli yang menentukan kinerja superior (Narver dan Slater, 1990). Orientasi pasar dapat diamati dan merupakan kemampuan atau sumber daya perusahaan yang tidak dapat ditiru, dan biasanya menempatkan kebutuhan pelanggan dalam inti strategi dan operasi organisasi (Ali et al., 2017).

Orientasi penjualan mengacu pada pengusaha yang terlibat dalam kegiatan penjualan yang membutuhkan "mendapatkan penjualan" dari setiap pelanggan (Jaramillo et al., 2007). Orientsasi penjualan merupakan sebuah pendekatan yang berfokus pada penjualan sebanyak mungkin dimana kebutuhan pelanggan diprioritaskan dalam lingkungan kerja yang mendukung (Boles et al., 2001).

Kinerja usaha adalah konstruk multidimensi yang mencakup hasil operasional dan keuangan perusahaan. Dalam Ini mengintegrasikan pengetahuan terkait industri, keterampilan manajemen dan motivasi pribadi (Phelan \& Sharpley, 2012). Faktor yang mempengaruhi kinerja usaha adalah kemampuan wirausaha dalam hal pengetahuan, keterampilan, dan kemampuan yang berharga dapat memfasilitasi kinerja usaha (Tehseen \& Ramayah, 2015).

Kinerja usaha merupakan suatu proses kognitif antara kewirausahaan dan hubungannya dengan serangkaian keterampilan dengan karakteristik demografis, psikologis dan perilaku dan keterampilan teknis (Linan, 2008).

Kerangka Pemikiran dalam peneletian ini seperti yang digambarkan dibawah ini:

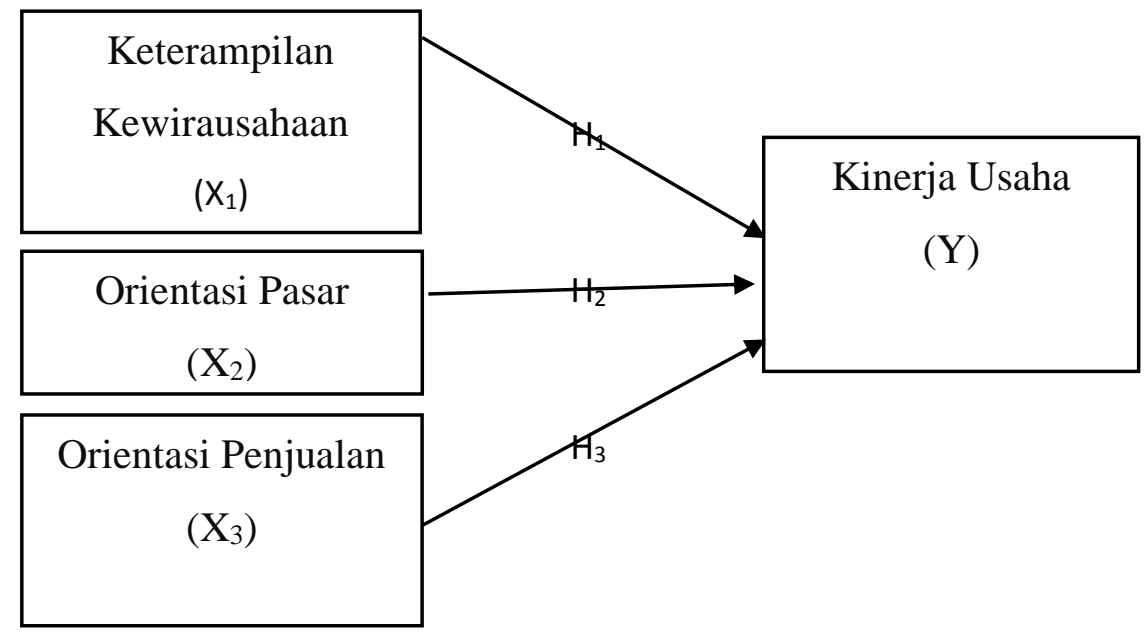

Gambar 1. Kerangka Pemikiran

Hipotesis dari model yang dibangun di atas adalah sebagai berikut:

H1: Keterampilan kewirausahaan memiliki pengaruh terhadap kinerja usaha mikro kecil dan menengah pada bidang kuliner di Jakarta Utara

H2: Orientasi pasar memiliki pengaruh terhadap kinerja usaha mikro kecil dan menengah pada bidang kuliner di Jakarta Utara

H3: Orientasi penjualan memiliki pengaruh terhadap kinerja usaha mikro kecil dan menengah pada bidang kuliner di Jakarta Utara 


\section{METEDOLOGI}

Dalam penelitian ini, peneliti menggunakan metode penelitian deskriptif. Penelitian deskriptif dapat membantu peneliti untuk memahami karakteristik suatu kelompok dalam situasi tertentu, berpikir secara sistematis tentang sebuah aspek dalam situasi tertentu, menawarkan ide untuk masalah dan penelitian dimasa yang akan datang, membantu membuat keputusan yang sederhana (Sekaran \&amp; Bougie, 2013). Metode deskriptif merupakan metode yang digunakan untuk menggambarkan atau menganalisis suatu hasil penelitian tetapi tidak digunakan untuk membuat kesimpulan yang lebih luas (Sugiyono, 2005).Pada penelitian ini, populasi yang diambil adalah wirausaha di Jakarta, dengan sampel yaitu wirausaha pemilik UMKM di Jakarta Utara, maka itu kuesioner diberi judul: "PENGARUH KETERAMPILAN KEWIRAUSAHAAN,ORIENTASI PASAR DAN ORIENTASI PENJUALAN TERHADAP KINERJA USAHA UMKM."

Teknik pemilihan sampel yang digunakan dalam penelitian ini adalah teknik tak acak purposive. Teknik ini digunakan atas dasar kemudahan unsur populasi untuk dijangkau. Untuk itu, unsur populasi yang lebih mudah dapat diperoleh datanya untuk itu unsur itulah yang dapat dijadikan sampel.

Jenis data yang dapat digunakan dalam penelitian ini adalah data primer. Data primer adalah seluruh data yang telah dikumpulkan sendiri oleh peneliti agar dapat menjawab suatu permasalahan penelitiannya.

Skala Likert dinyatakan sebagai skala nominal karena alternatif tanggapannya bersifat kategorik yang dinyatakan dalam lima kategori, yaitu: (1) sangat tidak setuju, (2) tidak setuju, (3) netral, (4) setuju dan (5) sangat setuju.

\section{HASIL UJI STATISTIK}

Pengujian validitas data dalam penelitian ini diukur dengan menggunakan nilai loading factor, convergent validity, dan discriminant validity. Nilai loading factor harus dapat lebih besar dari 0,6 dan jika nilai loading faktor dibawah dari 0,4 maka indikator tersebut dapat dihapuskan. Untuk mengukur nilai convergent validity dapat diukur melalui nilai Average Variance Extracted (AVE) yaitu harus dapat lebih besar dari 0,7 dan nilai loading faktor diatas 0,6. nilai loading factors dalam penelitian ini mempunyai nilai diatas 0,6 . Dengan nilai tertinggi dalam indikator OPJ02 yaitu Orientasi Penjualan 0,969 dan nilai terendah terdapat dalam indikator OPS07 yaitu Orientasi Pasar sebesar 0,913. Sehingga dapat disimpulkan bahwa semua indikator yang digunakan dalam penelitian ini telah memenuhi syarat. .

Pengujian Reliabilitas data dalam Penelitian ini menggunakan cronbach's alpha dan composite reliability untuk dapat menguji reliabilitas. Suatu data dapat dinyatakan reliabel jika hasil dari nilai cronbach's alpha $>0,6$ dan juga mempunyai nilai composite reliability (CR) lebih besar atau sama dengan 0,7. Berikut ini merupakan hasil dari nilai cronbach's alpha dan composite reliability. Cronbach's alpha Keterampilan Kewirausahaan mempunyai nilai 0,954, Orientasi Pasar mempunyai nilai 0,988, dan Orientasi Penjualan mempunyai nilai sebesar 0,968, selanjutnya Kinerja Usaha mempunyai nilai 0,969 dan composite reliability Keterampilan Kewirausahaan mempunyai nilai 0,967, Orientasi Pasar mempunyai nilai 0,989, dan Orientasi Penjualan mempunyai nilai sebesar 0,977, selanjutnya Kinerja Usaha mempunyai nilai 0,976 .

$\mathrm{R}^{2}$ digunakan untuk menilai variasi pengaruh antara variabel independen terhadap variabel dependen (Ghozali, 2014). Apabila nilai R-square diatas 0,75 maka mempunyai pengaruh yang kuat, sedangkan 0,5- 0,74 mempunyai pengaruh yang sedang dan 0,25-0,49 memiliki pengaruh yang lemah. Besarnya pengaruh $\mathrm{X}_{1}, \mathrm{X}_{2}$, dan $\mathrm{X}_{3}$ terhadap $\mathrm{Y}$ pada penelitian ini adalah sebesar $98.3 \%$. Sedangkan sisanya yaitu $1.7 \%$ dipengaruhi oleh variabel 
lain yang tidak terdapat dalam penelitian ini. Hal ini dapat diartikan bahwa setiap perubahan yang terjadi pada variabel keterampilan kewirausahaan, orientasi pasar, dan orientasi penjualan terhadap kinerja usaha juga ikut mengalami perubahan sebesar $98.3 \%$.

Pengujian path coefficients memiliki nilai dimana variabel keterampilan kewirausahaan memiliki pengaruh terhadap kinerja usaha sebesar 0.001, variabel orientasi pasar memiliki pengaruh terhadap kinerja usaha sebesar 0.000 , variabel orientasi penjualan memiliki pengaruh terhadap kinerja usaha sebesar 0.016 .

Pengujian Goodness of Fit (GoF)Untuk dapat melakukan pengujian kecocokan model dalam penelitian ini, nilai GoF (Goodness of Fit) dapat dihitung dengan cara manual dengan memasukan nilai AVE dan nilai koefisien determinasi. Berikut ini merupakan perhitungan nilai Goodness of Fit $(\mathrm{GoF})$ :

$$
\begin{aligned}
& \overline{A V E}=0,897 \\
& \overline{R^{2}}=0,983 \\
& \text { GOF }=\sqrt{\overline{A V E} x \overline{R^{2}}} \\
& \text { GOF }=\sqrt{0,897 \times 0,983}
\end{aligned}
$$

GOF $=0,939$

Pengujian Hipotesis yang telah dilakukan dalam penelitian ini untuk dapat menentukan apakah hipotesis-hipotesis yang telah dibuat dalam penelitian ini mempunyai pengaruh yang siginifikan. Pengujian hipotesis penelitian ini dilihat dari nilai t-statistik atau p-values.

Dapat diketahui bahwa t-statistik harus memiliki nilai > 1,96 dan p-values dibawah 0,05 (5\%). Sehingga dapat disimpulkan bahwa variabel independen (X) variabel dependen (X) keterampilan kewirausahaan, orientasi pasar dan orientasi penjualan mempunyai pengaruh yang signifikan terhadap variabel dependen (Y) yaitu Kinerja usaha.

Berdasarkan hasil pengujian yang telah dilakukan pada variabel keterampilan kewirausahaan (X1) terhadap kinerja usaha (Y) memiliki nilai T-statistic yaitu sebesar 3.202 dan P valuesnya yaitu sebesar 0.001 , maka H10 ditolak karena diketahui nilai T-statistic lebih besar dari 1,96 dan $\mathrm{P}$ valuesnya lebih kecil dari 0.05 , dari penjelasan diatas maka dapat dijelaskan dan disimpulkan bahwa keterampilan kewirausahaan memiliki pengaruh yang signifikan terhadap kinerja usaha pada bidang kuliner di Jakarta Utara.

Berdasarkan hasil pengujian yang telah dilakukan pada variabel orientasi pasar (X2) terhadap kinerja usaha (Y) memiliki nilai T-statistic yaitu sebesar 5.641 dan $\mathrm{P}$ valuesnya yaitu sebesar 0.000, maka H20 ditolak karena diketahui nilai T-statistic lebih besar dari 1,96 dan $\mathrm{P}$ valuesnya lebih kecil dari 0.05 , dari penjelasan diatas maka dapat dijelaskan dan disimpulkan bahwa orientasi pasar memiliki pengaruh yang signifikan terhadap kinerja usaha pada bidang kuliner di Jakarta Utara.

Berdasarkan hasil pengujian yang telah dilakukan pada variabel orientasi penjualan (X3) terhadap kinerja usaha (Y) memiliki nilai T-statistic yaitu sebesar 2.416 dan $\mathrm{P}$ valuesnya yaitu sebesar 0.016, maka H30 ditolak karena diketahui nilai T-statistic lebih besar dari 1,96 dan $\mathrm{P}$ valuesnya lebih kecil dari 0.05 , dari penjelasan diatas maka dapat dijelaskan dan disimpulkan bahwa orientasi penjualan memiliki pengaruh yang signifikan terhadap kinerja usaha pada bidang kuliner di Jakarta Utara.

Penjelasan uji hipotesis di atas, maka dapat dikatakan bahwa variabel keterampilan kewirausahaan, orientasi pasar dan orientasi penjualan memiliki pengaruh yang signifikan terhadap Kinerja usaha. 


\section{DISKUSI}

Hasil pengujian hipotesis variabel keterampilan kewirausahaan terhadap kinerja usaha mikro kecil menengah pada bidang kuliner di Jakarta Utara, memiliki nilai T-statistic yaitu sebesar 3.202 dan P valuesnya yaitu sebesar 0.001, yang berarti H10 ditolak. Dapat diartikan bahwa variabel keterampilan kewirausahaan memiliki pengaruh yang signifikan terhadap kinerja usaha.

Hasil dari penelitian ini sejalan dengan salah satu penelitian yang berjudul "Entrepreneurial knowledge, skills, competencies and performance" yang menjelaskan bahwa bahwa keterampilan kewirausahaan memiliki efek yang positif terhadap kinerja usaha, keterampilan kewirausahaan merupakan keterampilan atau keunggulan kompetitif yang berkontribusi pada kinerja perusahaan dengan melibatkan interaksi sosial (Abdullah et al., 2019).

Karenanya untuk meningkatkan kinerja usaha dari suatu perusahaan atau usaha, perusahaan perlu memiliki karakteristik interaksi sosial yang baik, dan perusahaan juga perlu terus mengasah keterampilan kewirausahaannya dengan menambah ilmu pengetahuan untuk membangun dan mengoprasikan perusahaan dengan bantuan dari penggunaan sumber daya untuk mencapai keunggulan yang kompetitif yang diharapkan oleh perusahaan. Keterampilan dan keyakinan kewirausahaan sangat penting bagi perusahaan karena hubungannya dengan proses kognitif dan serangkaian keterampilan. Perusahaan perlu mengadopsi karakateristik keterampilan kewirausahaan yang melibatkan interaksi dalam suatu lingkungan sosial dan material yang berguna untuk merujuk pada kegiatan atau pengetahuan yang dapat menciptakan kesuksesan bagi perusahaan

Hasil pengujian hipotesis variabel orientasi pasar terhadap kinerja usaha mikro kecil menengah pada bidang kuliner di Jakarta Utara, memiliki nilai T-statistic yaitu sebesar 5.641 dan P valuesnya yaitu sebesar 0.000, yang berarti H20 ditolak. Dapat diartikan bahwa variabel orientasi pasar memiliki pengaruh yang signifikan terhadap kinerja usaha.

Hasil penelitian ini sejalan dengan penelitian yang dilakukan oleh Morgan et al., (2009) yang menyatakan bahwa orientasi pasar mempengaruhi kinerja usaha secara langsung. Pendekatan dengan berorientasi pasar yang efektif dapat memfasilitasi organisasi untuk tampil luar biasa ketika mereka memahami kebutuhan dan keinginan konsumen mereka, strategi dan kemampuan pesaing, persyaratan dan pengembangan saluran distribusi, dan lingkungan pasar yang lebih luas.

Maka dari itu perusahaan yang memiliki orientasi pasar diharapkan dapat mendukung penjualannya dan mendorong kompetensi dari wirausaha. Wirausaha yang responsif terhadap pasar dan mengetahui tujuan utamanya yang merupakan memenuhi kebutuhan pelanggan akan dapat menjamin kinerja usahanya dengan memiliki strategi dan operasi untuk kebutuhan pelanggan. Orientasi pasar juga menjadi stau budaya dalam organisasi untuk meningkatkan kompetensi perusahaan yang berguna untuk menciptakan nilai yang superior bagi konsumen dan mendapatkan kinerja yang superior pada perusahaan. Orientasi pasar yang optimal akan membuat perusahaan juga melakukan promosi, mengumpulkan dukungan, dan terus menerus menciptakan suatu nilai yang efektif dapat memfasilitasi organisasi untuk tampil baik ketika mereka menjalankannya. Perusahaan yang menerapkan budaya organisasi juga dapat menempatkan kebutuhan pelanggan dalam inti strateginya dan operasi dalam perusahaannya.

Hasil pengujian hipotesis variabel orientasi penjualan terhadap kinerja usaha mikro kecil menengah pada bidang kuliner di Jakarta Utara, memiliki nilai T-statistic yaitu sebesar 2.416 dan P valuesnya yaitu sebesar 0.016 yang berarti H30 ditolak. Dapat diartikan bahwa variabel orientasi penjualan memiliki pengaruh yang signifikan terhadap kinerja usaha.

Hasil dari penelitian ini sejalan dengan penelitian dari Wachner et al., (2009) yang menjelaskan bahwa orientasi penjualan memiliki pengaruh pada kinerja usaha. Pendekatan 
yang berfokus pada penjualan dan prioritas akan kebutuhan pelanggan akan menciptakan keunggulan kompetitif perusahaan sehingga dapat meningkatkan kinerja usaha secara langsung.

Berdasarkan hasil penelitian, variabel orientasi penjualan memiliki hubungan yang negatif terhadap kinerja usaha. Wirausaha pada daerah Jakarta Utara hanya berfokus kepada profitabilitas atau keuntungan dan tidak mengedepankan persepsi dari pelanggannya. Persepsi dan keinginnan konsumen sangat penting dalam orientasi penjualan karena perusahaan akan mendapatkan informasi seputar produk yang cocok dengan ekspetasi dari konsumen. Maka dari itu wirausaha perlu selalu mengembangkan orientasi penjualan dalam hubungannya dengan kinerja usaha untuk meningkatkan layanan berbasis pelanggan dan mengelola menejemen hubungan pelanggan sehingga mengarah kepada kinerja usaha yang lebih baik dalam perannya untuk berinteraksi dengan pelanggan karena akan membantu dalam pembuatan produk baru yang kemudian akan terfokus pada peningkatan penjualan dan pengembangan produk mereka di masa depan dan tentunya akan meningkatkan kinerja usaha.

\section{PENUTUP}

Terkait dengan penelitian yang telah dilakukan, ada beberapa saran yang diharapkan dapat bermanfaat, berikut saran- saran dari peneliti: 1) Wirausaha perlu terus menerapkan keterampilan kewirausahaan, karena perannya dalam keterampilan dan proses kognitif untuk membawa perusahaan memiliki keunggulan yang kompetitif sehingga dapat berkontribusi pada kinerja usaha dan profitabilitas yang lebih baik. 2)Wirausaha perlu terus menerapkan orientasi penjualan, wirausaha perlu memperhatikan, menekankan dan mengukur kepuasan pelanggan, karena dengan demikian wirausaha dapat memiliki pendekatan yang berfokus pada pelanggan untuk mendorong kompetensi usahanya. 3) Wirausaha perlu terus menerapkan orientasi pasar, dalam hal ini wirausaha dituntut untuk membawa perusahaan selalu memenuhi kebutuhan pasar atau memenuhi kebutuhan pelanggan dengan melakukan promosi atau srategi dan operasi yang akan mendukung kinerja usahanya.

\section{DAFTAR PUSTAKA}

Abdullah Al Mamun, S. A. (2019). Entrepreneurial knowledge, skills, competencies and performance. Journal of International Management.

Ali, G., Hilman, H., \& Gorondutse, A. (2018). The effect of entrepreneurial orientation, market orientation, total quality management and organizational culture on the SMEs performance: a theoretical framework. Journal of Business and Retail Management Research, Vol. 12 No. 3.

Boles, J., Howard, W., \& Donofrio, H. (2001). An investigation into the inter-relationships of work-family conflict, family-work conflict and work satisfaction. Journal of Managerial Issues, Vol. 13 No. 3, pp. 376-390.

Boso, N., Story, V., \& Cadogan, J. (2013). Entrepreneurial orientation, market orientation, network ties, and performance: study of entrepreneurial firms in a developing economy. Journal of Business Venturing, Vol. 28 No. 6, pp. 708-727.

Gerli, F., Gubitta, P., \& Tognazzo, A. (2011). Entrepreneurial competencies and firm performance: an empirical study. VIII International Workshop on Human Resource Management Conference Proceedings, Seville.

Jaramillo, F., Ladik, D., Marshall, G., \& Mulki, J. (2007). A meta-analysis of the relationship between sales orientation-customer orientation (SOCO) and salesperson job 
performance. Journal of Business and IndustrialMarketing, Vol. 22 No. 5, pp. 302310.

Kohli, A., \& Jaworski, B. (1990). Market orientation: the construct, reseacrh propositions, and managerial implications. Journal of Marketing, Vol. 54, 1-18.

Liñán, F., \& Chen, Y. (2009). Development and cross-cultural application of a specific instrument to measure entrepreneurial intentions. Entrepreneurship Theory and Practice, Vol. 33 No. 3, pp. 593-617.

Mitchelmore, S., \& Rowley, J. (2010). Entrepreneurial competencies: a literature review and development agenda. International Journal of Entrepreneurial Behavior and Research, Vol. 16.

Morgan, N., Vorhies, D., \& Mason, C. (2009). Market orientation, marketing capabilities, and firm performance. Strategic Management Journal, Vol. 30 No. 8, pp. 909-920.

Nabiswa, F., \& Mukwa. (2017). Impact of credit financing on human resource development among micro and small enterprises: a case study of Kimilili Sub County, Kenya. Asian Journal of Management Science and Economics, Vol. 4 No. 1, pp. 43-53.

Phelan, C., \& Sharpley, R. (2012). Exploring entrepreneurial skills and competencies in farm tourism. Local Economy: The Journal of the Local Economy Policy Unit, Vol. 27 No. 2, pp. 103-118.

Pyysiäinen, J., Anderson, A. M., \& Vesala, K. (2006). Developing the entrepreneurial skills of farmers: some myths explored. International Journal of Entrepreneurial Behavior and Research, Vol. 12 No. 1, pp. 21-39.

Raghuvanshi, J., \& Garg, C. (2018). Time to get into the action. Asia Pacific Journal of Innovation and Entrepreneurship, Vol. 12 No. 3, pp. 279-299.

Sekaran, U., \& Bougie, R. (2013). Research Methods for Business. United Kingdom: Jhon Wiley \&amp; Sons Ltd.

Sugiyono. (2005). Metode Penelitian Bisnis. Bandung: Alfabeta.

Tehseen, S., \& Ramayah, T. (2015). Entrepreneurial competencies and SMEs business success: the contingent role of external integration. Mediterranean Journal of Social Sciences, Vol. 6 No. 1 ,.

Utama, L. and J.K. 2017. Pengaruh Kreatifitas Terhadap Kinerja Usaha Dengan Orientasi Kewirausahaan Sebagai Mediasi Pada Wirausaha di ITC Cempaka Mas. Conference on Managemant and Behavioral Studies. http://cmbs.untar.ac.id/images/prosiding/2017/p/Louis-utama-dan-jeremy-kristantonadi.pdf. Diakses Juni, 2020. 